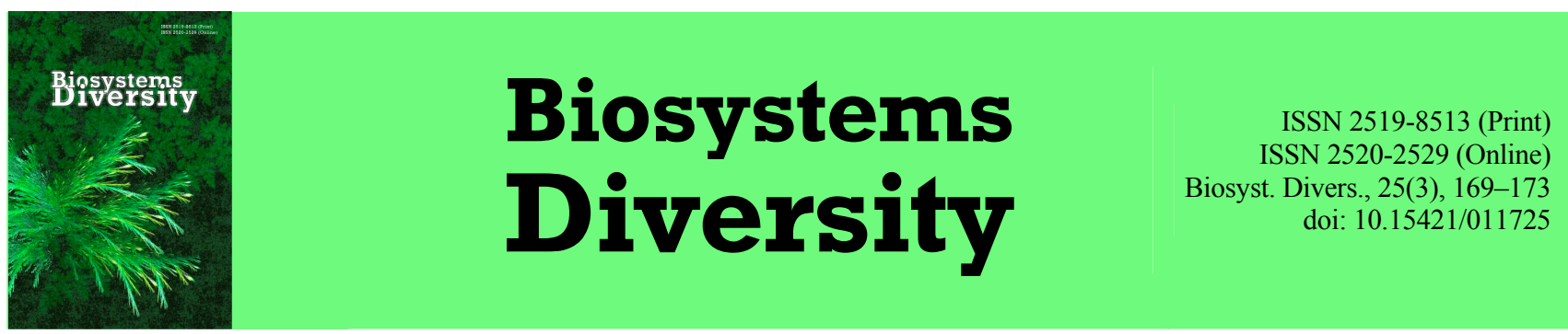

\title{
Patterns of multiannual changes in the spatial structure of a bank vole (Myodes glareolus) population in hornbeam-oak forest
}

\author{
S. A. Myakushko \\ Taras Shevchenko National University of Kyiv, Kyiv, Ukraine
}

Article info

Received 11.06.2017

Received in revised form 07.07.2017

Accepted 11.07.2017

National Taras

Shevchenko University of Kyiv,

Volodymirs'ka Str., 64/13,

Kyiv, 01601, Ukraine.

Tel.: +38-050-549-37-66

E-mail:aloizaloiz@ukr.net

\begin{abstract}
Myakushko, S. A. (2017). Patterns of multiannual changes in the spatial structure of a bank vole (Myodes glareolus) population in hornbeam-oak forest. Biosystems Diversity, 25(3), 169-173. doi:10.15421/011725
\end{abstract}

This article presents the results of research on changes in the spatial structure of a population of bank vole (Myodes glareolus Schreber, 1780) in the context of a study of multiannual dynamics of population density. The field research took place in Kaniv Nature Reserve, Cherkassy region, Ukraine, in May - June 2009-2012. In forest biotopes of the reserve the dominant mammal species is the bank vole The period of research spanned four consecutive phases of longterm dynamics of density of population of this species, and also of the rodent community in general (growth - peak decline - depression). The trapping of the animals was carried out by means of the traditional method of study plots. Parameters of spatial distribution of individuals - aggregation coefficient $(\mathrm{K})$ and density of individuals within concentrations (m) - makes it possible to gain an adequate impression of the structure of populations on the basis of data on distribution of individuals within the study plots. It has been established that the spatial structure of populations of rodents naturally changes in the course of multiannual dynamics of the population. During alternation of separate phases reorganizations of the spatial distribution of bank vole populations consisted of changes in quantity and the size of concentrations, and also density of their placement. A scheme of changes in spatial structure in conditions of cyclic fluctuations of density is presented. Absence of concentration during the depression phase of dynamics is defined by the insignificant number of consumers of environmental resources, which causes a surplus and availability of these resources and is indicated also by the fact that compact distribution of animals interferes with successful realization of reproductive potential. Intensive reproduction and rapid rate of increase in a population, which are characteristic of a growth phase, cause formation and growth of separate concentrations. Increase in their area prevents rapid growth of density within these populations, and action of negative effects of overpopulation is weakened by redistribution of young animals. The phase of peak population causes merging of borders between separate concentrations and the creation of a uniform concentration with a high internal density. Later (decline phase) such concentration breaks up into a number of small concentrations which are concentrated in the most optimum habitats. We found that multiannual "pulsation" of the spatial structure of a population occurs over absolutely different time periods and is similar to the seasonal pulsation. It is possible to draw analogies between separate phases (years) of dynamics and certain seasons because at such stages the development of populations has similar patterns.

Keywords: concentration; crowding; density; communities; Myodes glareolus

\section{Багаторічні зміни просторової структури популяцій рудої нориці (Myodes glareolus) грабової діброви}

\author{
С. А. Мякушко \\ Київський національний університет імені Тараса Шевченка, Київ, Украӥна
}

Досліджено закономірний характер змін просторової структури популяції рудої нориці (Myodes glareolus), а також усього угруповання лісових гризунів на території Канівського природного заповідника. Визначено параметри просторового розподілу (агрегованість $\mathrm{i}$ щільність організмів у скупченнях) упродовж різних фаз багаторічної динаміки щільності населення, на підставі яких запропоновано схему змін структури у разі циклічних коливань щільності. Відсутність агрегованості на фазі депресії визначається незначною кількістю споживачів ресурсів, що зумовлює надлишковість і доступність останніх, а також тим, що компактне розташування тварин перешкоджає успішній реалізації потенціалу відтворення. Напружене розмноження та швидкий темп збільшення популяції, характерні для фази росту, зумовлюють утворення та розростання поодиноких агрегацій. Збільшення їх площ запобігає швидкому росту скупченості всередині них, дія негативних ефектів перенаселення послаблюється шляхом розселення молодняка. Досягнення популяцією пікових значень своєї чисельності спричинює злиття меж між окремими скупченнями та утворення єдиної агрегації з високою внутрішньою щільністю. У подальшому (на фазі спаду) така агрегація розпадається на низку дрібних скупчень, які зосереджені в місцемешканнях із найсприятливішими умовами. Багаторічна та сезонна динаміка просторової структури популяції та угруповання гризунів у цілому, незважаючи на реалізацію у межах різних часових інтервалів, характеризуються схожими рисами.

Ключові слова: агрегованість; скупченість; щільність; угруповання; Myodes glareolus 


\section{Вступ}

Концепція циклічних змін стану популяцій живих організмів і пов'язані $з$ нею теорії регуляції коливань чисельності, хоча й мають давню історію, найчастіше знаходять своє відображення у вигляді абстрактних моделей для описання динамічних процесів у біосистемах. У такому контексті проблему гетерогенності самої біосистеми зазвичай розглядають у зв'язку з неоднорідністю середовища мешкання, тобто зовнішнього для біосистеми утворення (Chesson, 2000; Anderson et al., 2003; Shenbrot et al., 2010; Gómez Fernández et al., 2016). При цьому внутрішні тенденції розвитку системи ігноруються або відсуваються на другий план. Зазначене багато у чому справедливе для вивчення динаміки просторової структури популяцій тварин. Особливості мікрорельєфу, плямистість розподілу кормів, сховищ, інші зовнішні фактори, без сумніву, важливі, проте недостатні для осмислення результатів таких досліджень. Із поля зору дослідників часто випадає той факт, що популяція за допомогою змін своєї структури формує власне середовище, забезпечуючи реалізацію процесів саморегуляцiï (Selås et al., 2013; Benincà et al., 2015).

Існують підстави вважати, що під час циклічних коливань чисельності популяція здійснює переходи з одного стану в інший, змінюючи свої кількісні та якісні параметри (Krebs, 2013; Nystuen et al., 2014; Bian et al., 2015; Fauteux et al., 2015). Просторова структура також зазнає пульсуючих перетворень, у процесі яких відбувається стиснення та розширення простору, що використовується для забезпечення існування популяції (Mezhzherin and Semenjuk, 2001). На відміну від інших типів структури (статевої, вікової тощо), просторовий розподіл особин у популяціях гризунів був об'єктом досліджень у доволі обмеженому колі робіт (Efford, 2004; Miheev, 2005; Michel et al., 2007; Baláž and Ambros, 2012; Garrido-Garduno et al., 2016). Найчастіше увага науковців була зосереджена на сезонних аспектах динаміки просторової структури популяцій. Саме у цьому напрямку були здобуті найсуттєвіші результати, які свідчать про закономірний характер змін показників просторового розподілу впродовж року (Chistova, 1994; Semenjuk and Myakushko, 2000). Вдалося знайти та переконливо обгрунтувати «пульсацію» просторової структури у ході сезонної динаміки чисельності (щільності) населення. Необхідно враховувати наявність багаторічної динаміки чисельності, яка також демонструє циклічний характер. Цілком зрозуміло, що зміни популяційних показників під час процесів сезонної та багаторічної динаміки взаємопов'язані, які реалізуючись у межах різних часових інтервалів, накладаються один на одного.

Формування цілісного уявлення про цей тип структури та закономірності його змін неможливе без доповнення сезонних аспектів динаміки багаторічними. Ідеальний варіант досліджень передбачає одночасне їх розглядання на прикладі конкретної популяції, проте його реалізації у більшості випадків перешкоджає значна тривалість і трудомісткість польових спостережень.

Мета цієї статті - виявити закономірності змін просторової структури популяції домінантного виду та угруповання лісових гризунів у цілому під час багаторічного дослідження динаміки щільності населення.

\section{Матеріал і методи досліджень}

Польові спостереження проводили в Канівському природно-

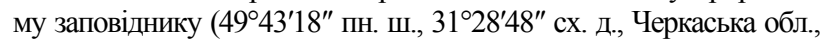
Україна) упродовж травня - червня 2009-2012 рр. Основою для роботи стали матеріали багаторічного безперервного моніторингу стану популяцій лісових гризунів грабової діброви заповідника, який здійснюється з 1971 року і до нашого часу. Фоновими для лісових біотопів заповідника є представники нориці рудої (Myodes glareolus Schreber, 1780) та підземної (Microtus subterraneus de Selys-Longchamps, 1836), а також миші жовтогорлої (Sylvaemus flavicollis Melchior, 1834). Перший із зазначених видів домінує в угрупованні гризунів, два інші - постійні мешканці діброви, показники щільності популяцій яких значно менші. Представники інших видів зустрічаються в окремі роки у незначній кількості, їх сумарна частка не перевищує $1 \%$ від загальної чисельності.

Період досліджень охопив чотири послідовні фази багаторічної динаміки щільності популяції нориці рудої, а також угруповання у цілому (ріст - пік - спад - депресія). Фази росту та спаду виділяли у випадках, коли щільність населення зростала (зменшувалась) упродовж двох років поспіль. Тварин відловлювали за допомогою традиційного методу облікових ділянок. У грабовому лісі ділянки розташовували на схилах із різною експозицією та вирівняних плато, охоплюючи території з різним ступенем розвитку підліска, трав'янистої рослинності та лісової підстилки. Залежно від поточної чисельності гризунів, для отримання необхідної вибірки закладали різну кількість облікових площадок. За час досліджень проаналізовано просторовий розподіл 845 особин домінуючого виду (загальна кількість особин трьох видів - 1412). Загальна площа 22 облікових ділянок складала 79,2 тис. м².

Особливості просторового розподілу індивідів - коефіцієнт агрегованості (K) та щільність організмів у скупченнях (m) вивчали за допомогою методик, запропонованих Ю. Е. Романовським та А. В. Смуровим (Romanovskij and Smurov, 1975; Smurov, 1975). У подальшому методики набули розвитку у працях інших авторів і знайшли своє застосування у процесі вивчення просторової структури популяцій тварин різних таксономічних груп (Carvajal-Villarreal et al., 2012; Taranec et al., 2012).

Показник К, який $\epsilon$ відношенням вільної (незаселеної) площі до загальної площі обстеження, та середня скупченість індивідів в агрегаціях дозволяють отримати адекватне уявлення про просторову структуру популяції на підставі даних про розподіл особин у межах облікових площадок. Статистичне оброблення матеріалу та аналіз вірогідності даних проведені загальноприйнятими методами. Оцінювання достовірності середніх значень i коефіцієнтів кореляції проводили стандартними методами, в останньому випадку з урахуванням кількості ступенів свободи.

\section{Результати}

Порівнюючи середні значення загальної щільності населення угруповання гризунів і популяції рудої нориці упродовж окремих фаз динаміки, можна побачити схожий характер багаторічних коливань щільності (рис.). Останнє зумовлено визначальним внеском домінуючого виду в сумарне населення. Коефіцієнт кореляції, розрахований між зазначеними показниками на досліджених облікових ділянках, свідчить про наявність сильного прямого зв'язку $(\mathrm{r}=0,931 ; \mathrm{P}<0,01)$. Слід зазначити, що амплітуда перепадів щільності гризунів у лісових біотопах заповідника не дуже значна, у 2010 р. хоча і був досягнутий найбільший за останні 20 років показник, проте він відрізнявся від мінімального лише у 4,4 раза. Попередніми дослідженнями доведено, що подібні циклічні коливання 3 характерним перебігом фаз динаміки відбуваються принаймні в останні три десятки років.

Незважаючи на те, що хронологічно першою у даному дослідженні є фаза росту щільності (2009р.), аналіз показників просторової структури доцільно розпочати з періоду низької щільності (фаза депресії). У такі роки показники агрегованості та щільності організмів у скупченнях мають значення, які наближаються до нуля (табл. 1). На час проведення польових спостережень тварини представлені в основному особинами, що перезимували, та представниками ранніх весняних генерацій. Чисельність їх відносно незначна, i на фоні навіть обмежених ресурсів середовища їх питома кількість не здійснює лімітувального впливу. Незважаючи на гетерогенність середовища, у таких умовах тварини розподіляються у просторі випадковим чином.

Подальший розвиток подій у популяції, чисельність якої циклічно змінюється, полягає у поступовому збільшенні населення. Саме на фазі депресії інтенсивність відтворення досягає 
максимуму (Ims et al., 2011). У результаті на початок періоду зимівлі у популяції створюється своєрідна «подушка безпеки» iз представників літніх і осінніх генерацій, більшість яких перебуває у стані «законсервованої молодості». Цей ефект неодноразово зафіксований, у тому числі в наших попередніх дослідженнях (Tkadlec and Zejda, 1998; Myakushko, 2016). Такі особини здатні швидко забезпечити не лише компенсацію втрат узимку, а й відновлення щільності ранньою весною. Саме це й відбулося на фазі росту популяції у 2009 році. Зміна просторової структури улітку цього року полягала у формуванні декількох великих агрегацій, проте скупченість організмів усередині них ще далека від максимуму.

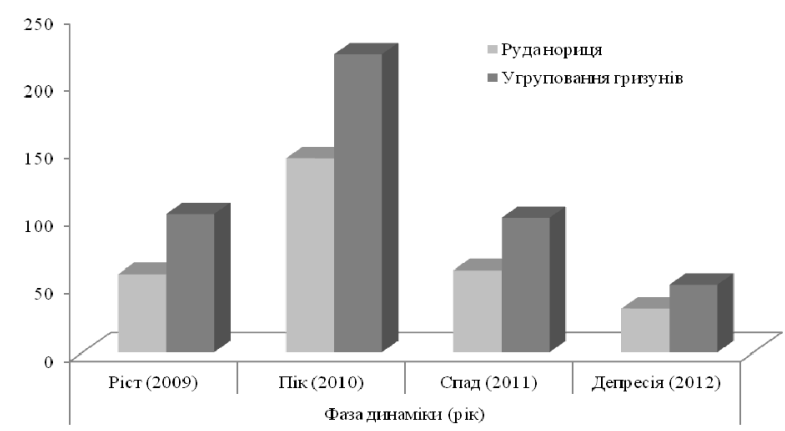

Рис. Зміни щільності популяції рудої нориці та угруповання лісових гризунів (ос./га) на різних фазах багаторічної динаміки населення

Таблиця 1

Коефіцієнти агрегованості (K) та показники скупченості індивідуумів в агрегаціях (m) на різних фазах багаторічного циклу щільності населення

\begin{tabular}{|c|c|c|c|c|c|}
\hline \multirow{2}{*}{$\begin{array}{c}\text { Фаза } \\
\text { циклу }\end{array}$} & \multirow{2}{*}{$\begin{array}{c}\text { Загальна площа } \\
\left(\mathrm{M}^{2}\right) \text { і кількість } \\
\text { облікових ділянок }\end{array}$} & \multicolumn{2}{|c|}{ Руда нориця } & \multicolumn{2}{|c|}{$\begin{array}{c}\text { Угруповання } \\
\text { лісових гризунів }\end{array}$} \\
\hline & & $K \pm m$ & $\mathrm{~m} \pm \mathrm{m}$ & $\mathrm{K} \pm \mathrm{m}$ & $\mathrm{m} \pm \mathrm{m}$ \\
\hline Pict & $21600(6)$ & $0,61 \pm 0,1$ & $0,43 \pm 0,08$ & $0,64 \pm 0,21$ & $0,48 \pm 0,10$ \\
\hline Пік & $18000(5)$ & 0,22 & & $0,13 \pm$ & $1,18 \pm 0,22$ \\
\hline Сп & 180 & $0,59 \pm$ & & $0,56 \pm 0,15$ & $0,91 \pm 0,17$ \\
\hline Депресія & $21600(6)$ & $0,02 \pm 0,0$ & $0,02 \pm 0,01$ & 0 & 0 \\
\hline
\end{tabular}

Зовсім інша ситуація притаманна фазі піка щільності окремої популяції та угруповання в цілому. В обох випадках незначні показники агрегованості супроводжуються найбільшою скупченістю тварин. Логічно припустити, що зменшення частини території, вільної від скупчень, зумовлене злиттям меж окремих агрегацій, у результаті чого практично вся доступна територія щільно заселена. У таких умовах кількість ресурсів у перерахунку на одну особину, зрозуміло, буде не високою. У разі обмеження здатності до розселення (наприклад, в острівних лісах, або в місцях із вираженою гетерогенністю умов) все це сприяє включенню механізмів автоматичного контролю $і$, як наслідок, зніманню негативних ефектів перенаселення в результаті уповільнення розмноження та збільшення смертності.

Легко помітити, що рівень щільності на фазах росту та спаду доволі схожий. Незважаючи на це, просторовий розподіл особин суттєво відрізняється. У рік спаду щільності одночасно зафіксовано високі показники агрегованості та скупченості. Останне свідчить про наявність багатьох незначних за площею агрегацій, проте 3 високою щільністю індивідуумів всередині. На цьому етапі існування популяції гризуни концентруються у найсприятливіших місцемешканнях, ймовірно, обираючи їх за кормністю або ступенем захищеності. Саме у таких місцях вони будуть займати вільні сховища або створювати нові, а формування нових агрегацій може бути зумовлене, наприклад, розселенням молодняку. На фазі росту щільності особини у популяції утворюють меншу кількість агрегацій, проте їх площа значніша. У цьому полягає загальна схема перебудов просторового розподілу організмів у ході чотирирічного циклу динаміки щільності населення.

Слід підкреслити певну схожість змін просторової структури популяції рудої нориці та усього угруповання гризунів. Багато у чому це пояснюється визначальним внеском домінуючого виду в загальне населення. Проте і на просторову структуру домінанта впливає кількість представників інших видів, а характер і сила таких взаємозалежностей далеко не однозначні. Це пояснюється не тільки різними рівнями щільності популяції інших видів в окремі роки, а i зміною ї екологічного статусу (субдомінант, сателіт) у результаті асинхронної циклічності. Оскільки порядок чергування та тривалість фаз динаміки у двох інших постійних мешканців грабової діброви специфічні, то i їх вплив на загальний просторовий розподіл особин буде неминуче відрізнятися упродовж окремих років.

Подібні взаємозв'язки можна прослідкувати, порівнюючи параметри К i m, а також зі значеннями щільності (табл. 2). Перше, що привертає увагу, це різна кількість сильних і достовірних коефіцієнтів кореляції у разі піка та депресії (на першій фазі їх у 7 разів більше). Характер скорельованості показників на двох інших фазах майже аналогічний.

\section{Таблиця 2}

Скорельованість показників щільності населення та просторової структури популяції рудої нориці та угруповання лісових гризунів

\begin{tabular}{|c|c|c|c|c|}
\hline \multirow{2}{*}{$\begin{array}{l}\text { Параметри, що } \\
\text { порівнюються }\end{array}$} & \multicolumn{4}{|c|}{ Фаза динаміки щільності } \\
\hline & ріст & пік & спад & депресія \\
\hline К РH $-\mathrm{m} Л \Gamma$ & $-0,204$ & $-0,132$ & $-0,269$ & 0,481 \\
\hline K PH - D ЛГ & 0,217 & $0,862 *$ & $-0,311$ & 0,129 \\
\hline К РН-К ЛГ & 0,504 & 0,114 & 0,466 & $-0,144$ \\
\hline K PH - m PH & $0,627 *$ & $-0,931 *$ & $0,819^{*}$ & $-0,120$ \\
\hline m PH - D ЛГ & 0,538 & $0,860^{*}$ & 0,504 & 0,063 \\
\hline D PH - D ЛГ & $0,604 *$ & $0,794 *$ & 0,634 & $0,894 *$ \\
\hline $\mathrm{mPH}-\mathrm{m} Л \Gamma$ & $0,894 *$ & $0,736^{*}$ & $0,772 *$ & $-0,312$ \\
\hline $\mathrm{DPH}-\mathrm{mPH}$ & $0,573^{*}$ & $0,904 *$ & $0,696^{*}$ & $-0,233$ \\
\hline К ЛГ - $\mathrm{m} Л Г$ & $0,821^{*}$ & $-0,889^{*}$ & $0,845^{*}$ & $-0,204$ \\
\hline
\end{tabular}

Примітки: D ЛГ - щільність населення в угрупованні лісових гризунів; D PH - щільність популяції рудої полівки; К РН - коефіцієнт агрегованості популяції рудої полівки; К ЛГ - коефіцієнт агрегованості угруповання; m PH - щільність населення всередині скупчень у популяції рудої полівки; $\mathrm{m}$ ЛГ - щільність населення всередині скупчень в угрупованні; * - значення коефіцієнтів кореляції з $\mathrm{P}<0,01$.

Сильний негативний зв'язок між К і m у рудої нориці на фазі піка свідчить про те, що зменшення вільних від агрегацій площ супроводжується зменшенням скупченості в них організмів. Пояснення цьому факту виглядає доволі очевидним: період масового розмноження супроводжується розселенням молодняку. Проте, зважаючи на досягнуті рекордні показники щільності, це слід розглядати з інших позицій - відбувається експансія окремих агрегацій, що закінчується формуванням, образно кажучи, єдиної агрегації. Негативні наслідки перенаселення послаблюються за рахунок того, що особини заселяють навіть ті місцемешкання, умови в яких далекі від оптимальних. Упродовж фаз росту та спаду між зазначеними показниками встановлюється прямий зв'язок: висока агрегованість поступово супроводжується щільною «упаковкою» індивідуумів усередині них. Тварини концентруються на найсприятливіших ділянках місцевості, а скупченість усередині агрегацій визначається досягнутою у поточному році щільністю.

Слід також звернути увагу на різний характер залежностей між показниками скупченості особин нориці всередині агрегацій i сумарної щільності населення гризунів. Те, що у разі збільшення показників останньої скупченість зростає, можна вважати передбачуваним ефектом. Дещо несподіваним виявилось одночасне зростання коефіцієнта агрегованості. Тобто збільшення загальної щільності угруповання супроводжувалося «компактністю» розміщення рудої нориці. Упродовж інших фаз динаміки значення коефіцієнтів кореляції низькі або недостовірні.

\section{Обговорення}

Ефективне використання ресурсів середовища слід вважати головною умовою виживання біосистем різного рівня. Простір 
можна розглядати як один 3 елементів із системи взаємопов'язаних ресурсів, отож його використання - засіб підтримання екологічного балансу. Наведені вище приклади добре ілюструють специфіку змін просторової структури протягом різних періодів існування біосистем. Циклічні зміни щільності населення та, відповідно, стану популяції (угруповання) супроводжуються циклічними перебудовами просторового розподілу організмів. Як уже зазначалося, в межах багаторічних коливальних процесів здійснюються циклічні сезонні зміни зазначеної структури. Тому доцільне співвіднесення результатів цієї роботи із даними щодо сезонних змін популяції нориці, отриманими нами раніше (Semenjuk and Myakushko, 2000).

У літній і зимовий сезони стратегія популяції спрямована на реалізацію процесів, що забезпечують, відповідно, репродукцію та виживання. У цих умовах надмірна щільність населення у скупченнях перешкоджає досягненню мети, що стоїть перед популяцією. Влітку, на фоні збільшення чисельності, запобігти подібних ефектів дозволяє розселення, яке супроводжується утворенням нових агрегацій на незайнятих територіях. Приблизно із середини осені, коли таких місць практично не залишається, а просторовий розподіл має вигляд однієї великої агрегації, щільність усередині скупчення визначається поточною кількістю тварин.

Коефіцієнти агрегованості в зимовий та літній періоди перебувають між собою у прямій залежності, чого не спостерігається восени. У свою чергу, щільність населення у скупченнях, як у популяції рудої полівки, так і в інших видів, позитивно скорельовані восени та взимку. В усіх випадках підвищення рівня заселеності скупчень відбувається в сезони 3 високою чисельністю та обмеженою здатністю до розселення.

Багаторічна «пульсація» просторової структури популяції, хоча і здійснюється в інших часових межах, демонструє риси схожості із сезонною. Між окремими фазами (роками) динаміки та певними сезонами можна провести навіть прямі аналогії, оскільки на таких етапах перед популяцією постають приблизно подібні завдання. Схожість завдань, у свою чергу, зумовлює схожість шляхів їх вирішення. Наприклад, у весняний сезон, а також у роки депресій, висока напруженість репродуктивних процесів спрямована на відновлення щільності населення (Nolet et al., 2013; Lehikoinen et al., 2016). Відсутність агрегованості пояснюється тим, що компактне розташування тварин перешкоджає успішній реалізації біотичного потенціалу. За малої кількості споживачів ресурсів тварини обирають найоптимальніші місцемешкання, не утворюючи у таких ділянках суттєвих скупчень. Іншими словами, недоцільно концентруватися в одному, навіть оптимальному просторі, якщо у середовищі існують інші, не менш сприятливі.

Велика кількість незначних за площею агрегацій, проте зі значною скупченістю особин усередині, притаманна зимовому сезону, а також фазі спаду щільності у багаторічній динаміці. Пріоритетне завдання для популяції - забезпечення виживання. У місцях наших досліджень зимове розмноження - не часте явище, тому основним завданням стає виживання індивідів, особливо тих особин, які у разі настання сприятливих умов здатні швидко включитися у відтворення. Є підстави вважати, що на перший план виходять кормність і захищеність місць мешкань.

Дефіцит ресурсів унеможливлює підтримання існування великих агрегацій. Напружене розмноження та швидкий темп збільшення популяції характерні для фази росту, а також літніх місяців (Lindén, 2010; Pinot et al., 2016). У такі періоди вже існуючі компактні агрегації починають швидко змінюватися, проте не за рахунок ущільнення, а через збільшення площі (експансії у просторі). Розселення молодняку зумовлює розширення меж агрегації, тому показник скупченості характеризується далеко не максимальними значеннями. Сезонним аналогом пікових років можна вважати осінні місяці. У цей період популяція найбільш гетерогенна (Ergon et al., 2010), інтенсивність розмноження хоча і знижується, але за рахунок масовості учасників, приріст чисельності доволі значний. У своєму максимальному вираженні це зумовлює заняття тваринами майже всього доступного простору та злиття меж окремих генерацій.

\section{Висновки}

Ефективне використання простору слід вважати одним із механізмів підтримання екологічного балансу між біосистемами різного рівня та їх середовищем. Просторова структура популяцій гризунів демонструє закономірний характер змін своїх параметрів (агрегованість і щільність організмів у скупченнях) упродовж багаторічної динаміки населення. Під час чергування окремих фаз, перебудови просторового розподілу особин у популяції рудої нориці полягають у зміні кількості та розмірів агрегацій, а також щільності їх «упаковки». Запропоновано таку схему змін просторової структури у разі циклічних коливань щільності. Відсутність агрегованості на фазі депресії динаміки визначається незначною кількістю споживачів ресурсів, що зумовлює надлишковість i доступність останніх, а також тим, що компактне розташування тварин перешкоджає успішній реалізації потенціалу відтворення. Напружене розмноження та швидкий темп збільшення популяції, характерні для фази росту, зумовлюють утворення та розростання поодиноких агрегацій. Збілышення їх площ запобігає швидкому росту скупченості всередині них, дія негативних ефектів перенаселення послаблюється шляхом розселення молодняку. Досягнення популяцією пікових значень своєї чисельності спричиняє злиття меж між окремими скупченнями та утворення єдиної агрегації 3 високою внутрішньою щільністю. У подальшому (на фазі спаду), така агрегація розпадається на низку дрібних скупчень, які зосереджені у місцемешканнях із найсприятливішими умовами. Багаторічна та сезонна динаміка просторової структури популяції та угруповання гризунів у цілому, незважаючи на реалізацію у межах різних часових інтервалів, характеризуються схожими рисами.

\section{References}

Anderson, C. S., Cady, A. B., \& Meikle, D. B. (2003). Effects of vegetation structure and edge habitat on the density and distribution of white-footed mice (Peromyscus leucopus) in small and large forest patches. Canadian Journal of Zoology, 81(5), 897-904.

Baláž, I., \& Ambros, M. (2012). Population analysis and spatial activity of rodents in flooded forest conditions. Ekológia (Bratislava), 31(3), 249-263.

Benincà, E., Ballantine, B., Ellner, S. P., \& Huisman, J. (2015). Species fluctuations sustained by a cyclic succession at the edge of chaos. Proceedings of the National Academy of Sciences of the United States of America, 112(20), 6389-6394.

Bian, J.-H., Du, S.-Y., Wu, Y., Cao, Y.-F., Nie, X.-H., He, H., \& You, Z. B. (2015). Maternal effects and population regulation: Maternal densityinduced reproduction suppression impairs offspring capacity in response to immediate environment in root voles Microtus oeconomus. Journal of Animal Ecology, 84(2), 326-336.

Carvajal-Villarreal, S., Caso, A., Downey, P., Moreno, A., Tewes, M., \& Grassman, L. I. (2012). Spatial patterns of the margay (Leopardus wiedii; Felidae, Carnivora) at El Cielo Biosphere Reserve, Tamaulipas, Mexico. Mammalia, 76, 237-244.

Chesson, P. (2000). Mechanisms of maintenance of species diversity. Annual Review of Ecology, Evolution and Systematics, 31(1), 343-366.

Chistova, T. Y. (1994). Spatial organization of a bank vole population in a foreststeppe oak forest. Polish Ecological Studies, 20(3-4), 147-154.

Efford, M. (2004). Density estimation in live-trapping studies. Oikos, 106(3), 598-610.

Ergon, T., Ergon, R., Begon, M., Telfer, S., \& Lambin, X. (2010). Delayed density-dependent onset of spring reproduction in a fluctuating population of field voles. Oikos, 120(6), 934-940.

Fauteux, D., Gauthier, G., \& Berteaux, D. (2015). Seasonal demography of a cyclic lemming population in the Canadian Arctic. Journal of Animal Ecology, 84, 1412-1422.

Garrido-Garduno, T., Tellez-Valdez, O., Manel, S., \& Vazquez-Dominguez, E. (2016). Role of habitat heterogeneity and landscape connectivity in shaping gene flow and spatial population structure of a dominant rodent species in a tropical dry forest. Journal of Zoology, 298(4), 293-301.

Gómez Fernández, M. J., Boston, E. S. M., Gaggiotti, O. E., Kittlein, M. J., \& Mirol, P. M. (2016). Influence of environmental heterogeneity on the distribution and persistence of a subterranean rodent in a highly unstable landscape. Genetica, 144(6), 711-722. 
Ims, R. A., Yoccoz, N. G., \& Killengreen, S. T. (2011). Determinants of lemming outbreaks. Proceedings of the National Academy of Sciences of the United States of America, 108(5), 1970-1974.

Krebs, C. (2013). Population fluctuations in rodents. The University of Chicago Press, Chicago, Illinois.

Lehikoinen, A., Fraixedas, S., Burgas Riera, D., Eriksson, H., Henttonen, H., Laakkonen, H., Lehikoinen, P., Lehtomäki, J., Leppänen, J., Mäkeläinen, S. Niemimaa, J., Pihlajaniemi, M., Santaharju, J., \& Välimäki, K. (2016). The impact of weather and the phase of the rodent cycle on breeding populations of waterbirds in Finnish Lapland. Ornis Fennica, 93(1), 31-46.

Lindén, A. (2010). Conceptual and statistical modelling of environmental effects in population dynamics. Helsinki University Printing House, Helsinki.

Mezhzherin, V. A., \& Semenjuk, S. K. (2001). Rol' prostranstvennoj struktury populjacii ryzhej polevki Clethrionomys glareolus (Rodentia, Arvicolidea) v processah samoreguljacii [The role of spatial population structure of the bank vole Clethrionomys glareolus (Rodentia, Arvicolidae) in self-regulation processes]. Vestnik Zoologii, 35(4), 93-96 (in Russian).

Michel, N., Burel, F., Legendre, P., \& Butet, A. (2007). Role of habitat and landscape in structuring small mammal assemblages in hedgerow networks of contrasted farming landscapes in Brittany, France. Landscape and Ecological Engineering, 22(8), 1241-1253.

Miheev, A. V. (2005). Vlijanie migracii na mezhvidovye vzaimootnoshenija v soobshhestvah mikromammalij [Influence of migration on interspecies relations in micromammals communities]. Ekologija ta Noosferologija, 16(1-2), 73-79 (in Russian).

Myakushko, S. A. (2016). Spivvidnoshennya riznykh form minlyvosti v populyatsiyakh dvokh vydiv noryts' [The ratio of different forms of variability in populations of two species of voles]. Naukovi Zapysky Ternopil's'koho Natsional'noho Pedahohichnoho Universytetu imeni Volodymyra Hnatyuka. Serija Biologija, 67, 84-90 (in Ukrainian).

Nolet, B. A., Bauer, S., Feige, N., Kokorev, Y. I., Popov, I. Y., \& Ebbinge, B. (2013). Faltering lemming cycles reduce productivity and population size of migratory Arctic goose species. Journal of Animal Ecology, 82, 804-813.
Nystuen, K. O., Evju, M., Rusch, G. M., Graae, B. J., \& Eide, N. E. (2014). Rodent population dynamics affect seedling recruitment in alpine habitats. Journal of Vegetable Science, 25(4), 1004-1014.

Pinot, A., Barraquand, F., Tedesco, E., Lecoustre, V., Bretagnolle, V., \& Gauffre, B. (2016). Density-dependent reproduction causes winter crashes in a common vole population. Population Ecology, 58(3), 395-405.

Romanovskij, J. J., \& Smurov, A. V. (1975). Novyj indeks agregirovannosti i ego jekologicheskij smysl [New index of an aggregation and its ecological sense]. Vestnik Moskovskogo Universiteta. Serija Biologija, 3, 114-116 (in Russian).

Selås, V., Kobro, S., \& Sonerud, G. (2013). Population fluctuations of moths and small rodents in relation to plant reproduction indices in Southern Norway. Ecosphere, 4(10), 1-11.

Semenyuk, S. K., \& Myakushko, S. A. (2000). Zminy prostorovoyi struktury populyatsiyi rudoyi polivky ta uhrupovannya lisovykh hryzuniv pid chas sezonnoyi dynamiky shchil'nosti naselennya [Changes of spatial population structure of bank vole and woodsy rodents community during seasonal dynamics of population density]. Visnyk Kyyivs'koho Natsional'noho Universytetu imeni Tarasa Shevchenka. Biolohiya, 32, 53-55 (in Ukrainian).

Shenbrot, G., Krasnov, B., \& Burdelov, S. (2010). Long-term study of population dynamics and habitat selection of rodents in the Negev Desert. Journal of Mammology, 91(4), 776-786.

Smurov, A. V. (1975). Novyj tip statisticheskogo prostranstvennogo raspredelenija i ego primenenie $v$ jekologicheskih issledovanijah [New type of statistical spatial distribution and its application in ecological researches]. Zoologicheskij Zhurnal, 54(2), 283-289 (in Russian).

Taranec, I. P., Smurov, A. V., \& Kuznecova, N. A. (2012). Reprezentativnost' prob raznogo razmera pri uchete chislennosti i ocenke gorizontal'nogo raspredelenija pochvennyh kollembol [Different size sample representativeness in population accounting and estimation of soil-dwelling Collembola horizontal distribution]. Vestnik Moskovskogo Universiteta. Serija Biologija, 16(3), 44 48 (in Russian).

Tkadlec, E., \& Zejda, J. (1998). Small rodent population fluctuations: The effects of age structure and seasonality. Evolutionary Ecology, 12(2), 191-210. 